\title{
Naturalitas Islamisasi Ilmu Pengetahuan di Lembaga Pendidikan Islam
}

\section{Andarwati}

Dosen tetap STAIN Malang Jurusan Babasa dan Sastra Inggris

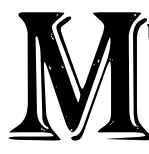

(unculnya konsep Islamisasi Ilmu Pengetabuan telah mengundang banyak perhatian dari berbagai kalangan sosial, termasuk dari kelompok praktikan lembaga pendidikan Islam. Suatu konsep yang pertama kali digulirkan oleh Al Faruqi ini diupayakan sebagai "filter" terutama terhadap "ilmu-ilmu Barat" yang tidak sesuai dengan normanorma Islam. Berbagai alternatif pemikiranbaik yang pro maupun yang kontra banyak dimunculkan sehubungan dengan praktek islamisasi ilmu pengetahuan dalam dunia pendidikan. Lalu, bagaimana sebenarnya "naturalitas" islamisasi ilmu pengetahuan ini dalam lembaga pendidikan Islam?

Kalau kita meninjau kembali konsep "pendidikan", pada dasarnya pendidikan bertujuan untuk mengangkat harkat dan martabat manusia melalui suatu proses dalam bentuk transfer of knowledge dan transfer of values. Knowledge yang dimaksud adalah substansi ilmu pengetahuan dari suatu disiplin ilmu, sedangkan values adalah nilai-nilai yang terkandung dalam suatu disiplin ilmu yang diharapkan dapat diaplikasikan oleh pembelajar dalam konteks penggunaan atau penerapan disiplin ilmu tersebut.

Dalam islamisasi ilmu pengetahuan terjadi "fusi" antara ilmu pengetahuan dan nilai-nilai dari suatu disiplin ilmu dengan ilmu dan nilai-nilai Islam 
yang bersumber dari Al-Qur'an dan AlHadist. Di satu segi penggabungan antara substansi dan nilai-nilai dari suatu disiplin ilmu dengan nilai-nilai kaidah Islam adalah suatu upaya hasanah dengan dilatarbelakangi oleh paradigma bahwa suatu proses pendidikan itu tidak hanya menggali dan mengembangkan sains dan ketrampilan, tetapi juga berorientasi untuk "mencetak" masyarakat yang berperadapan Islam. Inilah esensi dari pendidikan Islam. Pendidikan Islam tidak hanya sebatas "corak" pendidikan yang berlatar belakang keagamaan. Zarkowi Soejoeti (1986) memberikan pengertian lebih terperinci tentang Pendidikan Islam. Pertama, "pendidikan Islam" adalah jenis pendidikan yang pendirian dan penyelenggaraannya didorong oleh hasrat dan semangat cita-cita untuk mengejawantahkan nilai-nilai Islam, baik yang tercermin dalam nama lembaganya maupun dalam kegiatan-kegiatan yang diselenggarakan. Di sini Islam berfungsi sebagai sumber nilai yang akan direalisasikan dalam seluruh kegiatan pendidikan. Kedua, pendidikan Islam memberikan perhatian sekaligus menjadikan ajaran Islam sebagai pengetahuan untuk program studi yang diselenggarakan. Di sini kata "Islam" ditempatkan sebagai bidang studi atau ilmu yang dikemas sedemikian rupa, dan diperlakukan sebagaimana ilmu yang lain.
Ketiga, pendidikan Islam mencakup kedua pengertian di atas. Hal ini berarti Islam ditempatkan sebagai sumber nilai sekaligus bidang studi atau ilmu yang dipasarkan lewat program studi yang diselenggarakan.

Dari pengertian yang diberikan oleh Zamroni ini jelas bahwa pendidikan Islam tidak sekedar "ciri khas" atau "corak" pendidikan keagamaan, tetapi di dalamnya membawa visi dan mengemban tanggung jawab akademik dan moral. Pendidikan Islam menitikberatkan pada upaya pencerdasan manusia dan penanaman nilai-nilai dan moral yang sesuai dengan nilai-nilai Ketuhanan dan kemanusiaan. Sehingga pendidikan Islam bukan hanya menyelenggarakan kegiatan jasmani berupa pengajaran materi dan ketrampilan semata tetapi juga mengaitkan semuanya itu dengan praktek amaliabnya yang berunsurkan nilai-nilai akhlak dan moral. Oleh karena itu perlu diperhitungkan kualitas mekanisme operasional kegiatan serta sistem substansi pendidikannya. Sehubungan dengan sistem substansi pendidikan Islam ini Drs. Hasbullah (1996:7) menyebutkan:

Pendidikan Islam tidak menghendaki terjadinya dikotomi keilmuan sebab dengan adanya sistem dikotomi menyebabkan sistem pendidikan Islam menjadi sekularistis, rasionalistis, empiris, intuitif dan materialistis. Keadaan yang 
demikian tidak mendukung tata kehidupan umat yang mampu melahirkan peradapan Islam.

Oleh karena itu dalam lembaga pendidikan Islam seyogyanya pembelajar tidak cukup hanya "dicekoki" dengan ilmu dan nilai-nilai sekuler saja, tetapi juga nilai-nilai spiritual yang secara landasan hukum Islam bisa dipertanggung jawabkan. Dari proses pembelajaran non dikotomi keilmuan seperti ini diharapkan akan menghasilkan output yang tidak hanya memiliki kemampuan intelektual tetapi juga memiliki kualitas moral yang baik, sehingga dapat dihindarkan adanya intelligence bias.

Kasus-kasus dalam masyarakat seperti, seorang dokter yang melakukan praktek aborsi (ilegal), atau seorang ahli kimia yang memproduksi pil ekstasi adalah praktek-praktek penyalahgunaan intelektual. Fenomena ini adalah output dari suatu proses pendidikan dimana pemeroleh ilmu menerapkan ilmu yang diperolehnya tanpa memperhatikan rambu-rambu moralitas. Sedemikian fatalnya jikalau kemampuan intelektual seseorang tidak dibarengi oleh kualitas moral yang tinggi sehingga kepintaran yang dimilikinya tidak digunakan untuk memintarkan orang lain, tetapi untuk minteri orang lain. Kehadirannya dalam masyarakat tidak memberikan kemaslahatạn tetapi sebaliknya malah membawa bencana dan kerusakan. Atas dasar inilah sehingga memasuk-kan unsur-unsur tauhid ke dalam substansi disiplin ilmu dipandang sebagai suatu kebutuhan dan tuntutan guna mencetak manusia seutuhnya, yakni manusia yang lengkap mempunyai unsur jasmani dan rohani, unsur nafs dan galb dengan memiliki kualitas intelektual dan moral. Inilah nilai "hasanah" dari praktek islamisasi ilmu pengetahuan.

Akan tetapi di sisi lain, untuk merumuskan substansi dan melakukan praktek pendidikan dengan basis islamisasi ilmu pengetahuan adalah suatu tantangan yang potensial mengingat untuk menuju ke sana perlu adanya tuntutan-tuntutan yang harus dipenuhi praktikan pendidikan. Seperti yang diungkapkan oleh Al Faruqi (1982) dalam Islamization of Knowledge, ada beberapa kerangka kerja yang digunakan untuk merumuskan praktek islamisasi ilmu pengetahuan, yaitu (1) Penguasaan disiplin ilmu modern, (2) Penguasaan akidah dan nilai-nilai Islam, (3) Penentuan relevansi antara akidah dan nilai-nilai Islam dengan masing-masing bidang ilmu modern, (4) Pencarian sintesa kreatif antara unsurunsur akidah dan nilai-nilai Islam dengan masing-masing bidang ilmu modern, (5) Pengarahan aliran pemikiran Islam ke jalan-jalan yang mencapai pemenuhan pola rencana Allah swt. 
Apa yang diungkapkan oleh Al Faruqi menunjukkan adanya tuntutan "kompleksitas kompetensi" untuk dapat memenuhi kriteria standard kelayakan pendidik dalam islamisasi ilmu pengetahuan. Pertama, untuk unsur substantif seorang pendidik dituntut memiliki multi kapabilitas yaitu:

(1) Seorang pendidik harus mampu menguasai materi untuk minimal 2 jenis bidang ilmu yakni suatu cabang ilmu pengetahuan modern, dan ilmu tentang akidah dan nilai-nilai Islam yang bersumber dari Al Qur'an dan $\mathrm{Al}$ Hadist.

(2) Seorang pendidik harus mampu menentukan relevansi substansi ilmu pengetahuan modern tersebut dengan unsur-unsur akidah dan nilai-nilai Islam. Hal ini tidaklah mudah dilakukan mengingat sifat dan jenis substansi bidang studi yang berbeda-beda, sehingga pengajar harus "jeli" untuk sebisa mungkin memasukkan unsurunsur Islami yang relevan dari berbagai aspek bidang studi tersebut.

(3) Seorang pendidik harus mampu berkreasi untuk menciptakan sintesasintesa pernikiran dan konsep dalam diri pembelajar sehingga mereka memperoleh pemahaman antara yang "baik" dan yang "buruk", antara yang "halal" dan yang "haram", antara yang "terpuji" dan yang "tercela", antara yang "berpahala" dan yang "berdosa" sehubungan dengan pengaplikasian ilmu pengetahuan dan ketrampilan yang dimilikinya. Orientasi sentral dari semua ini adalah menciptakan "ketaqwaan" kepada Allah dalam diri pembelajar sehingga memiliki kekuatan "rasa takut" untuk menempuh jalan yang tidak dikehendaki oleh norma-norma Islam di saat mengaplikasikan ilmu pengetahuan yang dimilikinya.

Kedua, untuk unsur non-substantif seorang pendidik dituntut untuk memiliki multi skills didaktik, antara lain ketrampilan menggunakan metode dan strategi pembelajaran yang sesuai dengan sifat materi dan tujuan pembelajaran, ketrampilan mengelola kelas (classroom management), manajemen pendidikan dan pengajaran, serta ketrampilan mengevaluasi proses dan hasil pembelajaran, yang praktisnya kesemuanya itu harus bertumpu pada unsur-unsur aqidah dan tauhid.

Baik unsur substantif maupun nonsubstantif tersebut harus direncanakan secara menyeluruh dan terpadu agar tujuan pendidikan berbasis islamisasi ilmu pengetahuan ini dapat tercapai, eperti dalam semboyan yang mengatakan "Lsck is the result of good planning, and good planning 
is the result of information well applied". Selain itu persiapan secara integral dan holistik terhadap unsur-unsur aplikasi konsep islamisasi ilmu pengetahuan ini harus dilakukan agar hasil yang maksimal dapat diraih.

\section{Penutup.}

Dari paparan diatas dapat disimpulkan bahwa bagi lembaga pendidikan Islam, islamisasi ilmu pengetahuan adalah suatu kebutuhan (need) karena dari substansi pembelajaran yang non dikotomi keilmuan ini diharapkan dapat menceta manusia yang memiliki kualitas intelektua dan moral, serta sebagai upaya preventi terhadap bias intelektual. Akan tetap perumusan substansi dan praktek pendidikan berbasis islamisasi ilmu pengetahuan iniadalah suatu tantangan yan potensial karena menuntut pendidik untuk memiliki multi kapabilitas dan multi skills yang kesemuanya harus bertumpu pad unsur-unsur akidah dan tauhid yang bersumber dari Al Qur'an dan Al Hadist, serta mampu memadukan unsur-unsus substantif dan nonstantif tersebut secare integral dan holistik.

\section{DAFTAR PUSTAKA}

1. Echols, John M, dan Hasan Shadily. 1995. Kamus Inggris-Indonesia. Jakarta: PT Gramedia Utama.

2. Fadjar, Malik. 1998. Madarasah dan Tantangan Modernitas. Bandung: Mizan

3. Hasbullah. 1996. Kopita Selekta Pendidikan Islam di Indonesia. Jakarta: PT.Raja Grafindc Persada.

4. De Queljoe, D.H. \& Gazali, D. 1966. Didaktik Umum. Bandung: Ganaco. 